\title{
Apple Quality and Calcium Content as Affected by Fertilizer Treatment
}

\author{
Senad Murtić1*, Rodoljub Oljača², Ivana Koleška², Hamdija Čivić \\ ${ }^{1}$ Department of Plant Physiology, Faculty of Agriculture and Food Sciences, University of Sarajevo, \\ 1000 Sarajevo, Bosnia and Herzegovina \\ ${ }^{2}$ Department of Plant Physiology and Nutrition, Faculty of Agriculture, University of Banja Luka, \\ 78000 Banja Luka, Bosnia and Herzegovina \\ ${ }^{3}$ Department of Plant Nutrition, Faculty of Agriculture and Food Sciences, University of Sarajevo, \\ 71000 Sarajevo, Bosnia and Herzegovina
}

Received: 13 January 2017

Accepted: 23 February 2017

\begin{abstract}
The study was carried out in 2015 in the experimental orchard of the Agropodrinje apple introduction centre in the Gorazde area. The impact of different methods of calcium fertilizer application on fruit quality and calcium content in the 'Idared' fruit of an 8-year-old apple tree were studied. Fruit mineral composition and quality parameters were estimated after harvest. Calcium fertilizers used in this research were Folifertil$\mathrm{Ca}$, calcium-ammonium nitrate $(\mathrm{CAN})$, and calcium oxide $(\mathrm{CaO})$. Folifertil-Ca was applied through leaves, and $\mathrm{CaO}$ and $\mathrm{CAN}$ were applied through soil. The method of application where CAN was applied in combination with Folifertil-Ca significantly increased the accumulation of $\mathrm{Ca}$ in apple leaves and fruits. Also, this method of calcium fertilizer application had the greatest impact on apple fruit firmness increase. In the present study sugar content and acidity of apple fruit did not differ significantly, regardless of the application method of calcium fertilizers.

The results of this study support the fact that the Ca uptake by plant roots and its transport to leaves and fruits are directly affected by a plant's transpiration rate. This fact suggests that in apple cultivation is better if calcium fertilizers applied through soil or in combination with foliage treatment.
\end{abstract}

Keywords: soil, nutrition, firmness, leaves

\section{Introduction}

A very important segment in apple production, and that is sometimes overlooked in practice, is adequate nutrition of apple fruits with calcium $(\mathrm{Ca})$. Ca deficiency increases the incidence of bitter pit and internal breakdown

*e-mail: murticsenad@hotmail.com

of apple fruit. Also, these fruits are very sensitive to attacks by different pathogens, significantly lose weight, and ripen earlier, which greatly contributes to reducing qualitative and market value of fruits [1]. For preventing such occurrences of apple fruits it is necessary to provide sufficient amounts of $\mathrm{Ca}$, which in apple cultivation is made by treatments with $\mathrm{Ca}$ fertilizers. Mentioned fertilizers may be applied through the plant root system and through leaves, and each of these treatments has its advantages and disadvantages. The majority of scientists agree that 
the Ca nutrition of an apple is best if fertilizers are applied through soil, i.e., the plant's root system, primarily for easier uptake of $\mathrm{Ca}$ from root surface, and there are two basic ways in which calcium ions make contact with the root surface for plant uptake: root interception and mass flow [2-3]. The advantage of apple nutrition through the application of $\mathrm{Ca}$ fertilizers through soil is also that the apples needed for $\mathrm{Ca}$ are rather high and can be settled with difficultly solely by nutrition through the leaf [4]. However, in conditions when quick reaction is needed (for example when symptoms of Ca deficiency have already been noticed on apple), then foliar application of $\mathrm{Ca}$ has priority.

The basic advantage of foliar nutrition is that this method of application enables rapid efficiency of applied nutrients, since they are supplied directly to places where they are needed. The negative side of foliar nutrition is that $\mathrm{Ca}$ mobility through plant cells of leaves and fruits is very limited, resulting in the plant part not included by foliar treatment will not accumulate $\mathrm{Ca}$ [5]. Many scientists agree that $\mathrm{Ca}$ foliar nutrition has its place in plant nutrition, especially in conditions when possibilities of $\mathrm{Ca}$ uptake via root are very limited, for example in extremely acidic soils where the possibility of $\mathrm{Ca}$ binding to an adsorption complex of soil is significantly limited or in soils with high potassium and magnesium concentration that have an antagonistic relationship with $\mathrm{Ca}$ [6-7]. The main objective of this research was to examine the impact of $\mathrm{Ca}$ fertilizer application methods on its accumulation in leaves and fruits of the cv. 'Idared' apple grown in agroecological conditions of the Gorazde area. An additional objective of this research was to examine the impact of calcium fertilizer application methods on content of phosphorus $(\mathrm{P})$ and potassium $(\mathrm{K})$ in apple fruits and on quality parameters of apple fruits, sugar content or total soluble solids (TSS), acidity, and firmness.

\section{Material and Methods}

The experiment was conducted in 2015 in the orchard of the Agropodrinje apple introduction centre in the Gorazde area, and the tested plot implied a row of fruit trees that included 10 apple trees grafted on the same rootstock $\left(\mathrm{M}_{9}\right)$ and of the same age (8 years). Cultivation form (slender spindle), as well as planting distances $(1.3 \mathrm{~m} \times 3.5 \mathrm{~m})$ on all experimental plots of the tested site were identical.

Calcium fertilizers used in this research were Folifertil$\mathrm{Ca}$, calcium ammonium nitrate $(\mathrm{CAN})$, and calcium oxide $(\mathrm{CaO})$. Folifertil-Ca is a liquid foliar fertilizer that contains $8 \%$ nitrogen and $15.9 \%$ calcium. In accordance with manufacturer's instructions it is applied diluted with water at a concentration of $0.5 \%$ for apple trees. $\mathrm{CaO}$, also known as burnt lime, contains approximately $50-70 \% \mathrm{Ca}$, depending upon its source, while calcium-ammonium nitrate or CAN contains $8 \%$ calcium and $27 \%$ nitrogen.

Quantities of fertilizers that were added on studied plots were determined based on results of chemical analysis of soil, plot size, and calcium fertilizer application method.

Soil acidity was determined by $\mathrm{pH}$ meter, humus content by sulfochromic oxidation method, the content of available forms of potassium and phosphorus by using the AL method, and $\mathrm{CaCO}_{3}$ content of soil using a Scheibler calcimeter [8-11].

The results of soil analysis showed that experimental soil is neutral, with a medium content of available phosphorus and a high content of available potassium (Table 1). In accordance with these results the following recommendations were given and carried out identical to all plots: $400 \mathrm{~kg} / \mathrm{ha}$ NPK 5.20:30 as part of the autumn fertilization and $100 \mathrm{~kg} / \mathrm{ha}$ urea and $200 \mathrm{~kg} / \mathrm{ha}$ NPK 15:15:15 as part of fertilization during the growing season. Foliar treatment with microelement fertilizer (Folifertil B) was carried out before flowering.

A recommendation for calcium fertilization was also given, and it was conducted as part of the experimental trial.

The experimental trial was laid out in a randomized block design with four variants of calcium fertilizer application in three replications:

- Variant 1: control variant.

- Variant 2: six foliar treatments with $0.5 \%$ Folifertil Ca (applied as diluted solution).

- Variant 3: single application of $\mathrm{CaO}(1 \mathrm{t} / \mathrm{ha})$.

- Variant 4: single application of CAN (300 kg/ha), and three foliar treatments with Folifertil $\mathrm{Ca}(0.5 \%)$.

The application of $\mathrm{Ca}$ fertilizers, $\mathrm{CAN}$, and $\mathrm{CaO}$ was performed through soil in the beginning of vegetation, while foliar treatment with Folifertil $\mathrm{Ca}$ was performed at the beginning, middle, and end of apple vegetation. Leaves and apples were collected at the stage of apple commercial maturity. TSS of apple was determined by refractometry, acidity by titrating with a standard solution of $\mathrm{NaOH}$ with phenolphthalein as an indicator, and fruit firmness by a penetrometer model FT 327 [12-14]. The content of Ca, $\mathrm{K}$, and $\mathrm{P}$ in the plant materials were determined by atomic absorption spectrophotometry (AAS Shimadzu 7000 AA), according to the instructions specified in the ISO 11047 method, after their extraction from dried leaves and fruits with nitrate $\left(\mathrm{HNO}_{3}\right)$ and sulphuric acid $\left(\mathrm{H}_{2} \mathrm{SO}_{4}\right)$ [15-16]. The data obtained were subjected to standard methods of the analysis of variance (ANOVA) and multiple tests $\left(\mathrm{LSD}_{0.05}\right)$ using Microsoft Excel 2003.

Table 1. Results of chemical analysis of soil.

\begin{tabular}{|c|c|c|c|c|c|c|}
\hline \multirow{3}{*}{ Soil } & $\mathrm{pH}$ & $\mathrm{pH}$ & $\mathrm{Humus}$ & $\mathrm{P}_{2} \mathrm{O}_{5}$ & $\begin{array}{c}\mathrm{K}_{2} \mathrm{O} \\
\mathrm{mg} / 100 \mathrm{~g}\end{array}$ & $\begin{array}{c}\mathrm{CaCO}_{3} \\
\%\end{array}$ \\
\cline { 2 - 7 } & 7.20 & 6.50 & 4.28 & 14.95 & 28.40 & 8.9 \\
\hline
\end{tabular}




\section{Results and Discussion}

Table 2 shows the content of $\mathrm{Ca}, \mathrm{P}$, and $\mathrm{K}$ in examined samples of plant material.

Data presented in Table 2 show that in all variants, $\mathrm{Ca}$ content in apple leaves and fruits were higher in comparison to control variant. The highest $\mathrm{Ca}$ content in apple leaves and fruits was determined in variant 4, where the method of $\mathrm{Ca}$ fertilizer application implied a combination of application of CAN through soil and Folifertil $\mathrm{Ca}$ treatment through leaves, and then in variant 3 where Ca fertilizer was applied exclusively through soil. In variant 2, where fertilizer was applied only through leaves, $\mathrm{Ca}$ content in leaves and fruits was considerably lower, from which can be concluded the fact that nutrition through soil contributes more to the accumulation of $\mathrm{Ca}$ in apple fruits, and which is compatible with results of many studies that have examined this issue [17-18]. The main advantage of $\mathrm{Ca}$ nutrition through soil is that the $\mathrm{Ca}$ present in soil as divalent cation $\left(\mathrm{Ca}^{2+}\right)$ easily enters the root apoplast along with mass flow of water and follows apoplastic or symplastic pathways to the xylem [19], while Ca nutrition through the leaf is complex and depends on many factors, primarily on morphological and anatomical characteristics of leaves and forms of $\mathrm{Ca}$ fertilizers. The efficiency of $\mathrm{Ca}$ nutrition through leaves also depends on the mobility of $\mathrm{Ca}$ in the plant. As opposed to most macronutrients, $\mathrm{Ca}$ has low mobility within the plant, especially from leaves to fruit [20]. In accordance with this fact it is important that Ca nutrition through leaves is carried out by direct treatment of fruits with a $\mathrm{Ca}$ fertilizer containing more readily absorbable forms of $\mathrm{Ca}$, such as $\mathrm{Ca}\left(\mathrm{NO}_{3}\right)_{2}$ or $\mathrm{CaCl}_{2}$ [21-22].

A positive effect of the application of $\mathrm{Ca}$ fertilizers on $\mathrm{Ca}$ content of apple fruits is the method of application that includes foliar treatment with $1 \% \mathrm{Ca}\left(\mathrm{NO}_{3}\right)_{2}$ and $0.5 \% \mathrm{CaCl}_{2}$ as reported by Moor et al. [23]. However, the use of foliar fertilizers containing a much higher $\mathrm{Ca}$ concentration would disturb the osmotic equilibrium within leaf cells, and that would have a negative impact on the functions of plant tissue. This problem is seen as the key deficiency of Ca nutrition through leaves because the need for $\mathrm{Ca}$ is considerably higher than their concentration that can be placed in the foliar fertilizers without toxic effects on the leaves.

Table 2 data also showed that Ca content was several times higher in leaves in relation to apple fruits regardless of examined variants. The cause thereof is $\mathrm{Ca}$ transport dependence on transpiration intensity; plant parts that have higher transpiration intensity (leaves) also uptake Ca considerably more, while plant parts with lower transpiration intensity (fruit) have weaker $\mathrm{Ca}$ uptake, which consequently also leads to higher differences in $\mathrm{Ca}$ accumulation between apple leaves and fruits [24].

Dayod et al. [25] also found that Ca deficiencies are often manifested in plant tissues that have low relative rates of transpiration (fruit) compared with other parts of the plant, which clearly highlights the role of transpiration in the supply of $\mathrm{Ca}^{2+}$.

Interesting data in this research showed no great difference in Ca content of apple fruits between examined variants, although that difference was more than obvious when the subject of examination was calcium content in apple leaves. The reason for this can also be attributed to $\mathrm{Ca}$ transport dependency on transpiration intensity. Namely, as fruit ripens, the transpiration stream in fruits is lower so that Ca mobility in apple fruits is weaker, due to which differences in calcium content between fruits in examined variants are lower. Contrary to fruits, the leaves conduct transpiration intensively during their entire development, and thereby Ca uptake is more, so it is also to expect bigger differences in Ca content in apple leaves between examined variants, which is confirmed as well by results of this research..

$\mathrm{Ca}$ also has a very important role in increasing fruit storability. It is considered that apple fruits have good storage ability if they contain $\mathrm{Ca}$ in amounts above $4.5 \mathrm{mg} / 100 \mathrm{~g}$ of fresh fruit [26], and in the present study that was achieved in variant 4 , where Ca content in apple fruit amounted to $7.64 \mathrm{mg} / 100 \mathrm{~g}$ of fresh weight. In other variants of experiment $\mathrm{Ca}$ content in apple fruit was very close to limited value, which indicates that apple fruits meet or are very close to meeting previously specified criterion.

Apart from $\mathrm{Ca}$ content, the storage ability of apple fruits significantly depend on the content of other macroelements: primarily on $\mathrm{P}$ and $\mathrm{K}$ in apple fruits [27]. If the $\mathrm{P}$ content of apple fruits falls below the value of $9 \mathrm{mg} / 100 \mathrm{~g}$ of fruit, there is also a big danger of bitter spots occurring, especially in conditions when Ca content in apple fruits is very low [28]. In the present study values below $9 \mathrm{mg} / 100 \mathrm{~g}$ of fruit were not determined in any experimental variants, so that from this aspect, apple fruits in this study can be considered fruits with satisfactory storage ability. Contrary

Table 2. Ca, $\mathrm{P}$, and $\mathrm{K}$ content in examined samples of plant material (leaves and fruits).

\begin{tabular}{|c|c|c|c|c|c|c|}
\hline Experiment variant & $\begin{array}{c}\mathrm{Ca} \\
(\mathrm{mg} / \mathrm{kg} d r y \\
\text { leaves) }\end{array}$ & $\begin{array}{c}\mathrm{Ca} \\
(\mathrm{mg} / \mathrm{kgdry} \\
\text { fruit) }\end{array}$ & $\begin{array}{c}\mathrm{Ca} \\
(\mathrm{mg} / 100 \mathrm{~g} \\
\text { fresh fruit) }\end{array}$ & $\begin{array}{c}\mathrm{P} \\
\text { (mg/100 g } \\
\text { fresh fruit) }\end{array}$ & $\begin{array}{c}\mathrm{K} \\
(\mathrm{mg} / 100 \mathrm{~g} \\
\text { fresh fruit) }\end{array}$ & $\begin{array}{c}\mathrm{K} / \mathrm{Ca} \\
\text { ratio in fruit }\end{array}$ \\
\hline Var. 1 (control) & 6500.8 & 287.7 & 4.03 & 9.76 & 109.5 & 27.17 \\
\hline Var. 2 (Folifertil Ca) & 13532.2 & 301.0 & 4.13 & 9.72 & 110.6 & 26.78 \\
\hline Var. 3 (CaO) & 21653.2 & 313.0 & 4.47 & 9.15 & 106.5 & 23.83 \\
\hline Var. 4 (Folifertil Ca $+\mathrm{CAN})$ & 27651.8 & 611.3 & 7.64 & 9.41 & 108.5 & 14.20 \\
\hline
\end{tabular}


Table 3. Average values of quality parameters of apple fruits.

\begin{tabular}{|c|c|c|c|}
\hline Experiment variant & Fruit firmness $\left(\mathrm{kg} / \mathrm{cm}^{2}\right)$ & Total soluble solids TSS (Brix) & Acidity $(\%)$ \\
\hline Var. 1 (untreated) & $7.02 \pm 0.20 \mathrm{~b}$ & $12.94 \pm 0.02$ & $0.52 \pm 0.05$ \\
\hline Var. 2 (Folifertil Ca) & $7.14 \pm 0.24 \mathrm{~b}$ & $12.96 \pm 0.03$ & $0.48 \pm 0.02$ \\
\hline Var. 3 (CaO) & $7.42 \pm 0.36 \mathrm{~b}$ & $12.99 \pm 0.04$ & $0.47 \pm 0.04$ \\
\hline Var. 4 (Folifertil Ca + CAN) & $8.62 \pm 0.46 \mathrm{a}$ & $12.98 \pm 0.04$ & $0.51 \pm 0.05$ \\
\hline F test & s. & n.s. & n.s. \\
\hline LSD $_{0,05}$ & 0.62 & - & - \\
\hline
\end{tabular}

s: significant, n.s.: non significant

to $\mathrm{Ca}$ and $\mathrm{P}$ content, high $\mathrm{K}$ content in apple fruits is not desirable, more specifically a high ratio between $\mathrm{K}$ and $\mathrm{Ca}$ is not desirable in fruits. It is considered that apple fruits storage ability is significantly lower if $\mathrm{K}$ and $\mathrm{Ca}$ ratio in apple fruits is above 30:1 [29], which was not determined in this research in any experimental variants.

Average values of examined quality parameters of apple fruits depending on Ca fertilizer application methods are presented in Table 3.

From data presented in Table 3 it can be seen that variant 4 had the biggest impact on apple fruit firmness increase, in which Ca was applied in combination with the application of KAN through soil and Folifertil $\mathrm{Ca}$ through leaves, and that it was statistically considerably higher in relation to all other variants of the experiment. The apple fruits firmness in variant 2, where Folifertil Ca was applied through leaves, and in variant 3 , where $\mathrm{CaO}$ was applied through soil, was higher in relation to fruit firmness in the untreated variant, but that increase was not statistically justified. The specified data show that fruits with higher $\mathrm{Ca}$ content also have higher firmness than what was expected since the $\mathrm{Ca}$ is important for stability of membrane and plant cell wall. Namely, calcium is vital for firmness of apple fruit, being involved in the formation of calcium pectinates and oxalates that provide firmness of cell walls and membranes. When these parts are weakened, there is an uncontrollable loss of water, which contributes to fruit decay [30]. Positive correlation among the application of $\mathrm{Ca}$ fertilizers and fruit storage ability has been conformed in results of many scientific studies [31-33].

Table 3 data also show that in the present study there was no statistical difference in TSS and acidity of apple fruits between examined variants. The obtained results are in the same trend with the findings of Wójcik and Borowik [34], who reported that TSS content and acidity in apple fruit were not significantly influenced by the application of Ca fertilizers.

\section{Conclusions}

The results of this study support the fact that $\mathrm{Ca}$ uptake by plant roots and its transport to leaves and fruits are directly affected by a plant's transpiration rate.
This fact suggests that in apple cultivation it is better if calcium fertilizers applied through soil or in combination with foliage treatment. Ca fertilizers applied exclusively through leaves can also significantly contribute to better supplying fruits with calcium, as compared to the control variant, but in this method of application it is necessary to treat the fruit itself since the mobility of calcium through a plant cell of fruit is very limited.

All methods of application of $\mathrm{Ca}$ fertilizers had a positive effect to improve apple firmness, but only in variants where $\mathrm{Ca}$ was applied in combination with the application of CAN through soil and Folifertil $\mathrm{Ca}$ through leaves, which gave a statistically significant result.

In the present study the sugar content and acidity of apple fruit did not differ significantly, regardless of the method of application of calcium fertilizers.

\section{References}

1. FREITAS S.T., AMARANTE C.K.V., LABAVITCH J.M., MITCHAM E. J. Cellular approach to understand bitter pit development in apple fruit. Postharvest Biol. Tec. 57, 6, 2010.

2. VON BENNEWITZ E., COOPER T., BENAVIDES C., LOSAK T., HLUSEK J. Response of "Jonagold" apple trees to $\mathrm{Ca}, \mathrm{K}$ and $\mathrm{Mg}$ fertilization in an andisol in southern Chile. J. Soil Sci. Plant Nutr. 11, 72, 2011.

3. SALA F., IORDĂNESCU O., DOBREI A., JIVAN C. Contribution of foliar fertilization and calcium supplement in achieving apple production. J. Hortic. Sci. Biotech. 18, 151, 2014.

4. HOCKING B., TYERMAN S.D., BURTON R.A., GILLIHAM M. Fruit Calcium: Transport and Physiology. Front. Plant Sci. 7, 569, 2016.

5. LANAUSKAS J., KVIKLIENĖ N., USELIS N., KVIKLYS D., BUSKIENÉ L., MAŽEIKA R., STAUGAITIS G. The effect of calcium foliar fertilizers on cv. Ligol apples. Plant Soil Environ. 58, 466, 2012.

6. LODZE E., JOUBERT J., THERON K.I.V. Evaluating pre-harvest foliar calcium applications to increase fruit calcium and reduce bitter pit in „Golden Delicious“ apple. Sci. Hortic. 116, 299, 2008.

7. SHIRZADEH E., RABIEI V., SHARAFI Y. Effect of calcium chloride $\left(\mathrm{CaCl}_{2}\right)$ on postharvest quality of apple fruits. Afr. J. Agric. Res. 6, 5139, 2011. 
8. ISO 10390. Soil Quality, Determination of pH. International standard ISO 10390:1994. International Organization for Standardization, Geneve, Switzerland, 1994.

9. ISO 14235. Soil Quality, Determination of organic carbon by sulfochromic oxidation. International standard ISO 14235:1998. International Organization for Standardization, Geneve, Switzerland, 1998.

10. EGNER H., RIEHM H., DOMINGO W.R. Untersuchungen uber die Chemische Bodenanalyse als Grundlage fur die Beurteilung des Nährstoffzustandes der Böden II. Chemische Extraktionsmethoden zur Phosphor- und Kaliumbetimmung. Kungliga Lantbrukshögskolans annaler 26, 199, 1960.

11. HORVATH B., OPARA-NADI O., BEESE F. A simple method for measuring the carbonate content of soil. Soil Sci. Soc. Am. J. 69, 1066, 2005.

12. A.O.A.C. Official method 920.151; Solids (Total) in Fruits and Fruit Products with AOAC Official method. $17^{\text {th }}$ Edition, Washington, DC, USA, 2000.

13. A.O.A.C. Official method 942.15; Acidity (Titratable) of fruit products with AOAC official method. $17^{\text {th }}$ Edition, Washington, DC, USA, 2000.

14. ABBOTT J.A., WATADA A.E., MASSIE D.R. Effe-gi, Magness-Taylor and Instron fruit pressure testing devices for apples, peaches, and nectarines. J. Am. Soc. Hortic. Sci. 101, 699, 1976.

15. ISO 11047. Soil quality, Determination of cadmium, chromium, cobalt, copper, lead, manganese, nickel and zinc Flame and electrothermal atomic absorption spectrometric methods, International standard ISO 11047:1998. International Organization for Standardization, Geneve, Switzerland, 1998.

16. LISJAK M., ŠPOLJAREVIĆ M., AGIĆ D., ANDRIĆ D. Laboratory Plant Physiology. Faculty of Agriculture, Josip Juraj Strossmayer University of Osijek; 25, Croatia, 2009.

17. VERMA M.L., CHAUHAN J.K. Effect of integrated nutrient application on apple productivity and soil fertility in temperate zone of Himachal Pradesh. International Journal of Farm Sciences 3, 25, 2013.

18. DANNER M.A., SCARIOTTO S., CITADIN I., PENSO G.A., CASSOL L.C. Calcium sources applied to soil can replace leaf application in 'Fuji' apple tree. Pesquisa Agropecuária Tropical 45, 270, 2015.

19. DE BOER A.H., VOLKOV V. Logistics of water and salt transport through the plant: structure and functioning of the xylem. Plant Cell Environ. 26, 87, 2003.

20. HEPLER P.K, WINSHIP L.J. Calcium at the cell wall-cytoplast interface. J. Integr. Plant Biol. 52, 147, 2010.
21. LODZE E., JOUBERT J., THERON K.I. Evaluating preharvest foliar calcium applications to increase fruit calcium and reduce bitter pit in Golden Delicious Apple. Sci. Hortic. 116, 299, 2008V

22. SHIRZADEH E., RABIEI V., SHARAFI Y. Effect of calcium chloride $\left(\mathrm{CaCl}_{2}\right)$ on postharvest quality of apple fruits. Afr. J. Agric. Res. 6, 5139, 2011.

23. MOOR U, TOOME M., LUIK A. Effect of different calcium compounds on postharvest quality of apples. Agronomy Research 4, 543, 2006.

24. GILLIHAM M., DAYOD M., HOCKING B.J., XU B., CONN S.J., KAISER B.N. Calcium delivery and storage in plant leaves: exploring the link with water flow. J. Exp. Bot. 62, 2233, 2011.

25. DAYOD M., TYERMAN S.D., LEIGH R.A., GILLIHAM M. Calcium storage in plants and the implications for calcium biofortification, Protoplasma 247, 215, 2010

26. DRIS R., NISKANEN R., FALLAHI E. Nitrogen and calcium nutrition and fruit quality of commercial apple cultivar grown in Finland. J. Plant Nutr. 21, 2401, 1998

27. PERRING M.A. Mineral composition of apples. VII. The relationship between fruit composition and some storage disorders. J. Sci. Food Agr. 19, 186, 1968.

28. JOHNSON D.S. Influence of phosphorus sprays on the storage quality of apples. Acta Horticulturae 92, 327, 1980.

29. WINSKA-KRYSIAK M., LATA B. Influence of lipoxygenase activity and calcium and potassium contents on bitter pit occurrence in commercial apple cultivars. Folia Hort. 22, 13, 2010.

30. FRANCESCHI V.R., NAKATA P.A. Calcium oxalate in plants: formation and function. Annu. Rev. Plant Biol., 56, $51,2005$.

31. HUSSAIN P., MEENA M., DAR R., WANI A. Effect of post-harvest calcium chloride dip treatment and gamma irradiation on storage quality and shelf-life extension of Red delicious apple. Journal of Food Science and Technology 49, 415, 2012.

32. JAN I., RAB A., SAJID M. Influence of calcium chloride on storability and quality of apple fruits. Pak. J. Agr. Sci. 52, 115, 2015.

33. MATA A. P., VAL J., BLANKO A. Prohexadione-calcium effects on the quality of 'Royal Gala' apple fruits. J. Hortic. Sci Biotech. 81, 965, 2016.

34. WÓJCIK P., BOROWIK M. Influence of preharvest sprays of a mixture of calcium formate, calcium acetate, calcium chloride and calcium nitrate on quality and Jonagold apple storability. J. Plant Nutr. 36, 2023, 2013. 